\title{
SASKATCHEWAN'S HERITAGE MARSH PROGRAM
}

ORNE SCOTT, Box 995, Indian Head, Saskatchewan. SOG 2K0

The Heritage Marsh announcement on 5 November 1981 will be emembered as an important landmark or wetland conservation in Saskathewan. The agreement between Ducks Inlimited (Canada) and the Governhent of Saskatchewan with support rom the Saskatchewan Wildlife ederation, Nature Conservancy of Canada and Saskatchewan Natural History Society will preserve and hanage five major wetlands in Saskathewan.

The famed prairie potholes of the orthern great plains are one of the most iverse and productive ecosystems in he world. Unfortunately, our unique and mportant prairie marshes have been egarded as worthless wastelands, heant to be drained, destroyed and eveloped. Consequently, we have lost ver $40 \%$ of our original wetlands in askatchewan, and we continue to lose bout $2 \%$ of our remaining wetlands ach year.

The Heritage Marsh Program will cus much needed attention towards ur valuable wetlands. The program will ovide future generations with the oportunity to experience a Saskathewan marsh, to witness great flocks of igratory birds, and to be inspired and verwhelmed by the many sights, punds and activities of a prairie etland in springtime.

In addition to preserving valuable etlands for the benefit of all forms of Idlife, the Heritage Marsh Program will dress issues such as: waterfowl crop predation, flood and drought control, id sportsmen and naturalists interests.

In the Heritage Marsh agreement, ucks Unlimited (Canada) will totally fund construction and development costs for the marshes. The Saskatchewan Government will contribute crown land in the marshes and operate the crop damage prevention program under a federal-provincial crop damage agreement. The Saskatchewan Wildlife Federation, Ducks Unlimited, Nature Conservancy of Canada and Saskatchewan Natural History Society will all provide funds to secure land in marsh bottoms and will also purchase sufficient uplands for nesting cover and lure crops and bait stations to prevent waterfowl crop damage. These lands will be acquired through the Saskatchewan Wildlife Federation's "Habitat Trust Fund". The participating organizations will make contributions earmarked for Heritage Marshes to the "Habitat Trust Fund".

During the next five years the Saskatchewan Natural History Society will contribute several thousand dollats to the Heritage Marshes Program through donations to the "Habitat Trust Fund".

A list of 25 "key marshes" in Saskatchewan was reviewed before any Heritage Marshes were selected. To date, two projects: Ponass Lake near Rose Valley and the Thunder Creek Marshes northwest of Moose Jaw have been chosen for preservation and development. Several other very important marshes are being examined for their wildlife value. The remaining Heritage Marshes will be announced when this review process is completed.

The first Heritage Marsh, Ponass Lake, located five miles west of Rose Valley is an outstanding natural marsh, which serves as both a production and 
staging area for a number of birds. When completed, this project will encompass over 7,000 acres of actual marsh plus an outlying area to be managed as nesting cover and hay land. Controlled water levels will enhance stability within the marsh and improve hay production for local residents. Lure crops and bait stations are included in the design to prevent waterfowl damage to crops.

The Thunder Creek Marshes, northwest of Moose Jaw, will be the second Heritage Marsh project. Currently a lack of water in dry years threatens many wildlife species and also affects agriculture operations. By pumping water from Lake Diefenbaker, water levels will be managed to form about 8,000 acres of marsh consisting of Paysen, Williams, Kettlehut and Pelican Lake. A guaranteed source of water will benefit many species of wildlife and local residents in the area.

The Saskatchewan Natural History Society is very pleased to be a partner in this major conservation program in Saskatchewan. Not long ago, 'hunters' and 'bird watchers' had very little to do with each other. However, as we watch our natural habitat and wildlife disappear at an alarming rate, everyone's interest is at stake. The future of sportsmen, naturalists, bird watchers, nature photographers, scientists, hikers and a great many other people depends on our ability to preserve adequate natural habitat for all forms of wildlife.

In southern Saskatchewan, we have already lost $40 \%$ of our wetlands and $75 \%$ of our natural landscape has been destroyed. Several species of wildlife have already vanished, while others continue to disappear from much of their former range. Fifteen percent of our native plants are listed as rare or endangered.

The Heritage Marsh Program provides members of the Saskatchewan Natural History Society with the oppor- tunity to contribute to a significant conservation project right here at home. So that we can continue to enjoy our priceless natural heritage and future generations will have the same opportunities to observe, study and appreciate our vanishing wetlands, we ask for your contributions to one or both of our Society's conservation fund raising programs.

One fund raising project is the sale of Conservation Certificates for a donation of $\$ 20.00$ or more. The $9 \times 12$ inch color certificate is a print of a scenic painting of Saskatchewan wildlife by noted wildlife artist Fred Lahrman. The certificate, containing the donor's name, is suitable for framing and will be an attractive addition to your home or office. To obtain your Conservation Certificate send your donation of $\$ 20.00$ or more to the Saskatchewan Natural History Society c/o Lorne Scott, Box 995, Indian Head, Saskatchewan. SOG 2 KO. Receipts will be issued for in come tax purposes.

The second fund raising project is a conservation lottery. Fred Lahrman, long time member of our Society and ar. tist at the Saskatchewan Museum o Natural History has generously donated a framed $20 \times 28$ inch original painting of whistling swans for first prize. Only 5,000 one dollar tickets will be sold witt all proceeds going towards the Heri. tage Marsh Program.

In addition to Fred's painting there are nine other prizes including; nature books, framed nature photographs and a wood burning scene of waterfowl ove a marsh.

Tickets are available from provincia executive members and local societies You can obtain a book of ten ticket from Paule Hjertaas, 919 Coo Crescent, Regina, Saskatchewan. S4) 2L9. These tickets may only be sold legally within Saskatchewan. However members from outside the provinc 
may obtain tickets by sending payment (\$1.00 per ticket) to Paule. She will write your name and address on the tickets and return the stubs to you. (Because of mailing and handling costs, we urge members to order a minimum of three tickets.)

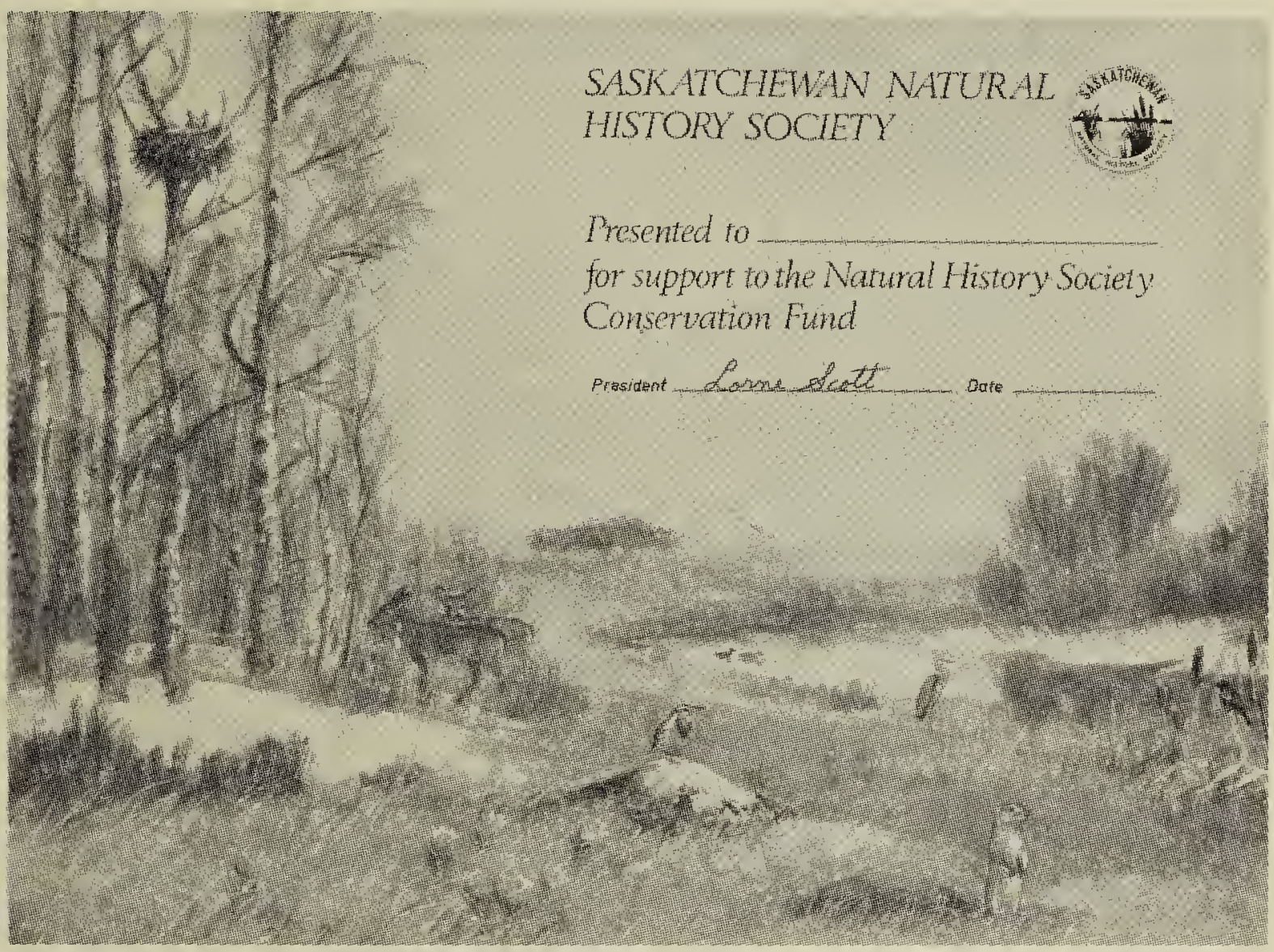

Conservation Certificate

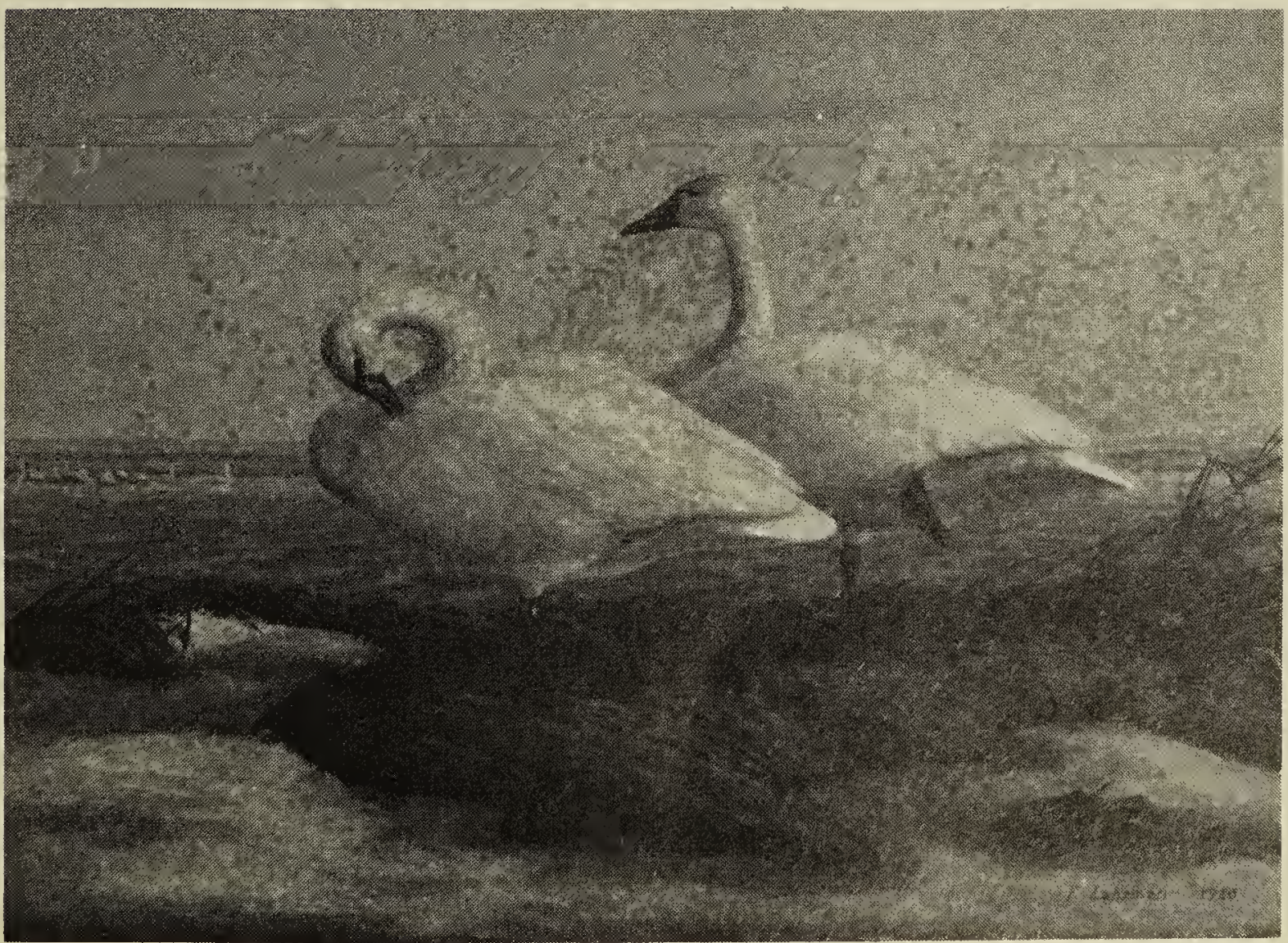

